\title{
PALEOECOLOGY OF THE ORDOVICIAN RADIATION: EVIDENCE FROM THE GREAT BASIN
}

DROSER, Mary L., Dept. of Earth Sciences, Univ. of California, Riverside, CA 92521; SHEEHAN, Peter M., Milwaukee Public Museum, Milwaukee, WI 53233; and LI, Xing, Dept. of Earth Sciences, Univ. of California, Riverside, CA 92521

The Ordovician is a critical junction in the history of life. Late Cambrian communities are vastly different from Late Ordovician ones; during the Ordovician, the Cambrian fauna was both taxonomically and paleoecologically replaced. In addition, community types that dominated the remainder of the Paleozoic were largely in place by the end of the Ordovician, in spite of the end Ordovician extinction. The nature of this paleoecological shift is not well understood. Large-scale patterns are well documented, but for the most part, record the end product.

At the basinal scale, data from the Great Basin of the western United States suggests that the paleoecology of this radiation was complex. Nonetheless, there are clear patterns that indicate that there were pivotal points, both taxonomically and paleoecologically during the radiation. New biofacies and habitats were developed, including a gastropod-oncolite biofacies, diverse hardground communities and sponge-microbial buildups. In addition, there are major shifts in communities in shallow marine soft-substrates where it appears that communities were reorganized several times. In the lowermost lower Ordovician strata, communities still retain a largely Cambrian aspect. In upper lower Ordovician strata, however, we record a transitional community - where both Cambrian and Ordovician elements are common. The base of the Whiterock is a pivotal point for many groups as well as for the development of shell beds. This boundary marks a major turnover in brachiopods and conodonts and marks the time when the trilobite clades that came to dominate the Paleozoic first appeared in North America and molluscan clades began a major diversification. Echinoderms contributed to the fossil record largely as encrinites. While echinoderms radiated in the Early Ordovician, they underwent another diversification in the Middle Ordovician, adapting to softsubstrata as recorded by Guensberg and Sprinkle (1992). Bryozoans first appeared and are a major component of hardground communities (Wilson et al., 1992). In contrast, tabulate corals (Eoflecharia and Lichenaria) first appeared but were inconspicuous through the Middle Ordovician. Articulate brachiopods continued to be dominant in the Upper Ordovician. Stromatoporoids were added and encrinites, tabulates, and rugosans were increasingly common. Trilobites were conspicuously rare but were certainly common though of low diversity elsewhere on the shelf as exhibited by the Cincinnatian strata.

Ordovician shell beds exhibit a distinct temporal pattern. Data indicate that: 1) the thickness, lateral extent, and internal complexity of shell beds increase from the Lower to Middle Ordovician, 2) the abundance of shell beds increases from the Lower to Middle Ordovician, and 3) Lower Ordovician shell beds are dominated by trilobites whereas Middle Ordovician shell beds are dominated by brachiopods and ostracodes. Trilobite dominated and exclusively trilobite beds are abundant in Lower Ordovician strata (Ibexian), but they do occur rarely as thin pavements or lenses in Middle Ordovician strata. Whereas brachiopod-dominated and exclusively-brachiopod beds predominate in Middle Ordovician strata (Whiterockian), they only rarely occur in Ibexian strata. While ostracodes, bryozoans and bivalves occur in Ibexian strata, shell beds formed from these taxa are restricted to Middle Ordovician and younger strata.

Most previous studies of the Ordovician Radiation are large-scale or focus on a single clade. While both of these approaches are critical to understanding radiations, we also need also to resolve these studies so that we can fully understand the dynamics of a radiation. While our study is still ongoing, it does demonstrate that field-based paleoecological studies over thick stratigraphic intervals are both possible and may provide insight into both the patterns and processes of a radiation. 